\title{
News Narratives across Borders: The Convergence of Interests and Patterns of Meaning in International Media Coverage of Disaster
}

Jamie Matthews

Bournemouth University

When covering significant global events, shared narratives may emerge across a globalised news media, circulating meaning and contributing to how publics make sense of issues and events (Cottle, 20I4). In turn, these narratives are reflected in the spaces made possible by digital media platforms and through the formation of a global discursive community (Guo, Holton and Jeong, 2OI2). Disasters, those that meet the criteria of proximity for western media (Benthall, I993) or are unusual in the scale of their impacts are exemplars of such global events, receiving worldwide media attention, with coverage that is open-ended, ritualised and often highly emotive (Cottle, 2006). By drawing on both media-system perspectives and the features attributed to the globalisation of journalism (Berglez, 2013), this chapter considers how shared narratives emerge through the representations of disaster in international news coverage.

While commonalties in coverage have previously been ascribed to hierarchies within a global media system, illustrated, for example, by the influence of a select group of satellite news channels (Cottle and Rai, 2006) and international news agencies on the selection, presentation and dissemination of news (Boyd-Barrett, 2008; Clausen, 2003; Wu, 2003), more recent research recognises

How to cite this book chapter:

Matthews, J. 202I. News Narratives across Borders: The Convergence of Interests and Patterns of Meaning in International Media Coverage of Disaster. In: Jonsson, H., Berg, L., Edfeldt, C. and Jansson, B. G. (eds.) Narratives Crossing Borders: The Dynamics of Cultural Interaction. Pp. 207-225. Stockholm: Stockholm University Press. DOI: https://doi .org/IO.I6993/bbj.j. License: CC-BY 4.0 
that mainstream news media are part of a complex and interconnected network of global communication (Heinrich, 20II). This enables a greater diversity of information and perspectives to circulate in the contemporary media environment, allowing alternative or counter-narratives to emerge and gain traction. Others suggest that similarities in news output are due to the norms, practices and values of journalism that are increasingly shared between different journalism cultures and contexts, for example approaches to newsgathering and the prominence now afforded to citizen material (Berglez, 20I3; Nygren and Stigbrand, 20I4).

To elaborate on these processes, this chapter will explore the narratives that emerged across global media coverage of the cascading disaster that Japan faced in March 20II. Through this case study and by drawing on approaches to networked journalism (Heinrich, 20I I), it will argue that the narrativisation of this event, not only reflected the structural influences on news but echoed ways of understanding, in this example advancing a cultural narrative that was premised on the dominant discourses on Japan.

\section{News and Narratives of Disaster}

There is a large body of research and scholarship that has explored the narrative features of news and journalism (Elliot, 2000, p. 355). It is grounded in the view that news accounts are more than simply about conveying information but instead journalism interprets events and constructs social reality (Bird and Dardenne, 2009; Johnston-Cartee, 2005, p. I 85 ). Many argue that narratives or frames rendered in news are a result of interactions between the different levels of discourse (Pan and Kosicki, I993). This includes the context, political, economic and sociocultural, in which news is produced, and the professional practices, values and discipline of journalism, the emphasis placed for instance on objectivity (Schudson, I978). Others highlight the features of journalistic discourse, news values, the genre and structure of news narratives, and how they determine what makes the news and how it is presented to audiences (Van Gorp, 2007).

The body of work on news as narrative distinguishes between master narratives, those common across coverage of different 
issues, and narratives intrinsic to the topic or event being reported (de Vreese, 2005). Neuman, Just and Crigler (I992) identified five overarching narratives that recur in news discourse, which they describe as economic, conflict, powerlessness, human-impact and morality frames. The conflict frame, to take one example, is a narrative present across a range of different topics that centres on discord and disagreement amongst different individuals, groups and organisations. This is evident in the way news media cover politics, where accounts will focus on the different positions adopted by individuals and political parties (See Aalberg, Stromback, de Vreese, 20II), to reporting on science and the environment, with reports emphasising the differences that exist in scientific opinion (See Tong, 20I4). Other master narratives reflect universal story forms, those of tragedy (Kitch, 2003), heroism, and good versus evil. Issue-specific narratives, in contrast, are the themes enacted to bring together stories that are about the same topic or event (de Vreese, 2005), thereby functioning as central organising ideas or 'interpretive packages' (Gamson and Modigliani, I989).

When narrating disaster news media coverage has been shown to follow familiar templates. Natural disasters are often presented as otherworldly, divine acts of God, reflecting dominant social and cultural understandings of disaster (Pantti, WahlJorgensen and Cottle, 20I2, p. 4). Journalism will also seek to tell the stories that demonstrate the human impact of disaster, providing compelling accounts of survival, loss and resilience. These human-interest stories are a consequence of news values, which place an emphasis on personalised, emotive accounts that resonate with audiences (Zelizer and Allan, 20I0, p. 55). Such stories often draw on the recognisable narrative frameworks of tragedy and heroism. Increasingly, these accounts are provided by those caught up in or witnesses to disaster, whose images, video or social media posts contribute to the narratives that unfold, offering an alternative perspective on disaster and their effects or contesting strategic narratives deployed by elites (Allan, 20I3). Other scholarship has considered how disaster news reflects mythic themes and motifs, stories that are "familiar, readily understood and easily digested" (Johnson-Cartee, 2005, p. I86), or perpetuate common disaster myths. One well-established myth is that 
communities affected by disaster will panic and experience disorder, a belief that is refuted empirically by the evidence that shows altruistic or prosocial behaviours are more typical in post-disaster environments (Rodriguez, Trainor and Quarantelli, 2006). This was illustrated through the mediated representations of postKatrina New Orleans, where news accounts advanced a narrative of lawlessness and anarchy that misrepresented the reality of the situation, reinforcing a political discourse that accentuated a need for social control in the management and response to this disaster (Tierney, Bevac and Kuligowski, 2006; Stock, 2007).

What is also significant about the narratives that emerge though news coverage of crises and disaster, is that they may act as representations of shared sentiments, for example through the expressions of grief and loss. In these periods of collective mourning such narratives will resonate with broader cultural symbols and can serve a ceremonial function by enabling societies to grieve and move on from disaster (Kitch, 2003, pI 5 ).

\section{Processes of Narrative Homogenisation}

Both the dynamics of the global flows of news and information, those that circulate around significant news events and issues, and common professional ideals and practices of journalism contribute to narrative coherence in the way disaster events are represented through media.

In traditional models the flow of information and content across borders has been attributed to hierarchies that exist in a global media system, one that has been "latently structured by the world's politics, economy and cultures" (Wu, 2003, p. 9). Attempts to analyse these flows have identified a western hegemony in the production and distribution of media content (Tunstall, 2008). In the provision of news this hierarchy is evident in news agendas, the issues and stories given space in foreign news coverage, and the overrepresentation of western countries and their interests (Himelboim, Chang, and McCreey, 20 Iо). Recent work advocates a more nuanced understanding of the dominant flows of news and information. Thussu (2006) argues that digital technology, the emergence of regional news broadcasters, such as Al-Jazeera, 
and greater internationalisation increase the flow and visibility of content, including news and entertainment media, emanating from other regional centres. These contraflows present alternative perspectives, represent diverse cultural outlooks and may be premised on different journalism models and values. While valuable, Thussu (2006) contends that their presence do not fundamentally alter the structural imbalances inherent within the global media system, in particular in the provision of information and news.

Watanabe (2013) attests that although audiences now have access to a greater diversity of news sources, aided by the growth of digital media and the flow of information through communicative spaces such as Twitter, western agendas and interests remain preeminent. This leads to an overrepresentation of western countries and a greater focus on news from and about western countries in foreign news reporting (Himelboim, Chang, and McCreey, 20I0), with stories from other regions and countries only making the news when certain thresholds are met (Gans, I980). For disasters occurring in economically less developed countries, it is their scale, the extent that they may impact on dominant geopolitical interests or their relevance to western audiences that determine their visibility (Pantti, Wahl-Jorgensen and Cottle, 2OI2), Consequently, the amount of coverage afforded to a disaster often corresponds with the number of western victims and its potential to create economic instability (Joye, 2009).

In the contemporary media environment, many recognise that the speed of transmission, interactivity and a greater diversity in sources are facilitating multidirectional flows of information (Castells, 2000; McNair, 2006). Heinrich (20II) proposes the concept of networked journalism, where news organisations are just one amongst many information nodes that comprise a complex web of global communication. Each node, whether it be the journalism produced by a news organisation, a blog, or individual tweet, can potentially connect to and influence each other. These networked perspectives acknowledge how alternative information sources have become prominent voices in global communication, afforded greater opportunities for access and reach by digital networks. Disasters, therefore, are represented through the flows of information that circulate around these events, with traditional 
media one amongst many different information streams that contribute to how disasters become signified and understood (Pantti, Wahl-Jorgensen and Cottle, 2012).

Despite these shifts towards more horizontal structures of global communication flows, questions of hierarchy and influence still remain. So, while the digital sphere provides access to different perspectives and can bring new information to bear, mainstream news organisations remain significant in setting agendas, defining the dialogical parameters and contributing to the framing of issues and events. As news organisations have sought to extend their reach by converging content across traditional and new media forms, with platforms such as Twitter and Instagram now used to source, report and distribute news, they have been able to enhance their agenda-setting and gatekeeping roles (Jenkins and Deuze, 2008).

Concentration in media ownership also serves to sustain dominant flows of news and information. Despite the emergence in recent years of regional players, such as China's Xinhua news agency, whose influence has increased in line with China's growing economic and political status (Tang and Iyengar, 20I2), three news agencies, the Associated Press (AP), Reuters and Agence France Press (AFP), still maintain a substantial market share (Boyd-Barrett, 2008). Studies of online news, including news aggregators such as Google News that bring together stories from different sources distributed across the web, have been shown, for example, to be reliant on the content provided by these agencies (Watanabe, 20I2). Others identify how the republication of articles from European and US newspapers, in particular from influential titles such as Le Monde (France), El Pais (Spain), the Guardian (UK) and the New York Times (US), serve to sustain a hierarchy in the flow of news (Tunstall, 2008).

Much scholarly attention has been paid to the established international news channels, including BBC World News and CNN, and satellite news networks broadcasting from other regional centres, most notably Al-Jazeera (Qatar), CCTV (China) and Russia Today, and their influence on global news flows. While some posit that the emergence of news organisations such as Al-Jazeera, have further eroded the western hierarchy in news ( $\mathrm{Si}, 2014$ ). Others 
contend that only a select group of international news channels, the most significant being CNN International and BBC World News, can really be described as global in their reach, (Rai and Cottle, 2007, p. 63). Volkmer (20I4, p. I60-I6I) argues that such international news channels are able to present a "a supranational news angle" by bringing together a breadth of information and perspectives. Even though the audience, which increasingly for this type of news are watching content on demand, may be small. They can be influential, "info elites" that are spread across different regions and countries. The reputation and quality of content provided by these international news channels allow them to operate as "supernodes" in the contemporary media system (Volkmer and Heinrich, 2008). While only one amongst many interlocutors contributing to a global public sphere (Volkmer, 20I4, pi62), their elevated position, as with other well-established news organisation, enables them to not only influence agendas but also through the representations that they construct to contribute to the narrativisation and interpretation of events. These narratives then circulate as dominant representations across national and linguistic borders.

It is also important to recognise how the convergence in global narratives to disaster can also, in part, be attributed to the discursive and professional practices of journalism. TV news agencies, such as Associate Press Television, Paterson (I998, p. 83 ) argues, produce content that appears to fulfil the criteria of objectivity and neutrality, which serve to present an "ideologically distinctive and homogenous view of the world," facilitating the construction of a "global TV image." In a similar vein, Volkmer (20I4) identifies transnational dimensions of objectivity and authenticity. Others emphasise a commitment to common professional ideals as a feature of an emerging form of globalised journalism where core journalistic values are becoming shared across different journalism cultures (Berglez 20I I). Comparative research on journalistic role conceptions shows, for example, that the value of information-disseminator, as a passive, objective recorder of information, is one that is now more commonly shared across journalism cultures, as opposed to a more active adversarial role (Weaver, I998). Such common practices and 
attitudes are a consequence of increasing interaction and cooperation between individual journalists, enabled by the opportunities afforded by global news organisations and the standardisation of journalistic routines facilitated by digital technologies, for example the use of social media for newsgathering (Reese, 2008). Others point toward the changing relationships between journalists and their audiences, where audiences now play a more active role in news production (Wardle and Williams, 20I0) or recognise broader shifts in societal organisation toward networked forms of interaction.

\section{Shared Narratives in International News Coverage of the 2011 Japan Disaster}

To consider further how these processes may contribute to narrative homogenisation across linguistic and cultural borders, I will now turn to the characteristics of international media coverage of the cascading disaster that befell Japan in 20I I.

On March II, 20I I a 9.0 magnitude earthquake struck just off Japan's Pacific coast, generating a series of tsunami waves that devastated coastal communities in the north east of the country. Damage caused by the earthquake and tsunami to reactor cooling systems at the Fukushima Daichi nuclear power plant led to a third disaster, with the partial meltdown of three reactor cores at the site and the release of radioactive material.

Evidence from other analyses shows that familiar narrative frameworks to disaster were rendered in the initial media coverage of the tsunami and its impacts, with the common constructs of apocalypse, catastrophe and the power of Mother Nature deployed to describe the disaster scene (Pantti, Wahl-Jorgensen and Cottle, 20I2). On March I 2, 20 I I the most widely circulated British newspaper, The Sun, ran a front-page headline that simply stated Apocalypse. This figurative construct of the immediate post-disaster environment was also apparent in different media contexts. Jeune Africa, a pan-African news magazine, described the disaster as Japon: l'Apocalypse (Japan: The Apocalypse) and in a photo essay published in Le Pont International, a French news magazine, as Japon: les images de l'apocalypse (Japan: images of 
the apocalypse). It was also evident in online coverage in Germany, for example in Der Spiegel (Japan's Apokalypse, I3 March), and in a piece published in Italy's la Republica newspaper (Apocalisse in Giappone, I 3 March).

Any similarities in narrative frames emerging during this initial phase of media coverage are indicative of the dominant discourses on disaster, which echo across different cultural contexts. These discourses are reflected in the established templates of disaster reporting, which are a consequence of journalists attempts to communicate the scale and impacts of a disaster to their audiences. It is the commonality of this template and its use within different journalism cultures, albeit the examples offered here are principally from European media, rather than any systemic factors influencing selection and presentation, that explain the recurrence of this narrative in news accounts.

Powerful visual accounts also circulated quickly across global news coverage, with many of these images and videos captured by ordinary people who were able to document the tsunami and its aftermath. Much of this footage was first obtained by Japanese broadcasters but was quickly picked up and used by other news organisations, evident from the Japanese imprinted in the original newscasts. Amateur footage of the tsunami inundating the small port city of Kesennuma, for example, was first broadcast by the All Nippon News Network (ANN) and the Japan Broadcasting Cooperation (NHK), but was then subsequently integrated into packages produced by the BBC, Russia Today, France 24 and CBS, amongst others. Global news agencies are also increasingly able to influence the flow or citizen and eyewitness material by sourcing, verifying and distributing this content to other news providers (Murrell, 20I7).The space afforded to such images in international news coverage contributed to this narrative of catastrophe by providing a visual record of the magnitude and power of the tsunami. Technology, the use of smartphones and the practice of sourcing and incorporating eyewitness material into journalistic accounts of disaster in particular, which by this time had generally been routinised into news organisations' reporting and production processes, may also explain the convergence of news narratives around these themes. 
The volume of content captured and shared by ordinary citizens in Japan following the earthquake and tsunami was unprecedented. Although much of this material was first disseminated through social networks, as videos uploaded to You Tube or images shared on Twitter and Mixi, mainstream news organisations enhanced its visibility by integrating it into their reporting on the disaster, through live news blogs for example ${ }^{\mathrm{I}}$ (Thurman and Rogers, 20I4). Journalism, therefore, maintained a role as gatekeeper (Jenkins and Deuze, 2008), enabling this content to become central to the repertoire of images that formed as narratives to this disaster. Prominent examples include images and video of people fleeing the approaching tsunami in the town of Minamisanriku in Miyagi and footage shot from higher ground by a local tour guide of the waves inundating the town of Rikuzentakata, Iwate. In reporting and communicating disaster, this citizen content is valuable since it gives voice to disaster victims (Cooper, 20II). Here, in the context of this disaster, it narrativized the impact of the tsunami upon disaster-affected communities.

There is also evidence to show that an economic master narrative emerged as one of the principal organising frameworks in coverage of the disaster, with its impacts expressed in terms of economics, both for Japan and for the global economy (Pantti, WahlJorgensen and Cottle, 20I2). One feature of this narrative was an interlacing of financial news with updates about the disaster. As a consequence, even reports that were structured around the disaster were often written from an economic perspective. There is a significant volume of news articles and packages published online that illustrate these narrative features, not only in content from the major international news outlets but from a range of different regional and national news providers. ${ }^{2}$ The complex flows of news and information that circulate around disaster and the hierarchies that exist within a global media system explain the prominence

I Live blogs are used by many news organizations to bring together original reporting, alongside aggregated news, comment and citizen content on a breaking or significant news story (Elliot, 20I6).

2 For example, see: Japan Quake: Economic Impact Felt Across Asia, $B B C$, I 8 March 20I I; Japan scrambles to shore up economy, Al-Jazeera, I 5 March 20II; Considerable economic impact from Japan quake, $A B C$, I3 March 201 I. 
of this economic narrative. Due to Japan's global economic position there were fears that the disaster, and a prolonged release of radiation at Fukushima, would have negative impact on a global economy still recovering from the 2008 financial crisis. The interests of elite nations, therefore, converged around an economic imperative, which was reflected in the way the disaster was communicated, debated and represented through international media coverage (Pantti, Wahl-Jorgensen and Cottle, 20I 2, p 55 ).

What is also significant, however, in the representations of this disaster was how ways of understanding, those premised on dominant discourses on and images of Japan, emerged as a shared narrative to the disaster. Discourses on Japan have a long history of emphasising cultural otherness and its difference from the West. This master narrative is sustained and reproduced through the contemporary mediascapes and the transborder flows and consumption of popular culture, news and information (Appadurai, I995). Research identifies how mediated representations of Japan, across film, television and news reporting, have tended to produce and reinforce its cultural difference (See Daliot$\mathrm{Bul}$, 2008). This narrative was revealed through the representations of “Japan's" response to the disaster. Commentators writing at the time noted that international news coverage emphasised the role of culture in explaining how people in Japan were coping in the aftermath of the tsunami and the worsening situation at Fukushima (Huang, 20I I; Rees, 20II). Subsequent analyses have also highlighted the frequency that references appeared in international media coverage to the stoicism, calmness and perseverance of the Japanese in the face of disaster (Iannarino, Veil and Cotton, 20I4; Pantti, Wahl-Jorgensen and Cottle, 20I2) and the use of a cultural framework to present human-interest stories to news audiences (Matthews, 2019)

There are various examples across different media that illustrate this narrative, from news and comment carried in influential international print titles, including The New York Times, the Guardian, Le Monde, and packages produced by international broadcasters such as CNN International. ${ }^{3}$ These pieces often drew

3 For example, see: The Japanese could teach us a thing or two, The New York Times, 20 March 20I I We all know the slogan keep calm and carry 
on stereotypical cultural traits, such as exploring a link between collectivist values and how people in Japan were responding to the disaster or integrated familiar images of Japan into its reporting on the disaster and its impacts. One example of this was the story of Tsuyako Ito, introduced in a piece first published in the Guardian newspaper on I8 March 20I I that described the post-disaster environment in Kamaishi city, Iwate. This article reflected on the longer-term difficulties she would face as a teacher of traditional Japanese dance and describing her as being known locally as the last geisha of Kamaishi (Watts, 20I I). Her story, framed as a cultural narrative through the foregrounding in news accounts of her occupation and interests in the traditional Japanese arts, was later picked up and reported in a range of different media outlets including the New York Times (4 April 20II), China Daily (25 April 20I I), and in El Universal (3 April, 2OII). A subsequent update on her situation also appeared in coverage of the first anniversary of the disaster in reports carried by Al-Jazeera (IO March 20I2) and Le Figaro (I6 March 20I2). Many initial reports credited AFP or the New York Times, but significantly not the Guardian, as the original source for the story. This underlines the importance of these global news outlets, one an international news agency, the other amongst the most widely read online newspapers (Sweeney, 20I4), in diffusing a cultural narrative to this disaster. Although we could argue that this story was selected and framed to resonate in one context by perpetuating a familiar image of Japan amongst western audiences, it was recycled across others and contributed to the emergence of this shared narrative to this disaster.

A second example is provided by the space afforded in the global media to the concept of jishuku, the exercise of self-restraint during a period of mourning that was practiced in Japan in the weeks after the disaster (Kingston, 2013). It was reported wide$1 y^{4}$ and became part of the conversation about the post-disaster

on, but would we? the Guardian, I9 March, 20I I; Amid disaster, Japan's societal mores remain strong, CNN, April I I, 20 I I.

${ }^{4}$ For example, in a package produced by the BBC (8 April 20II), which was broadcast by BBC World News, and in articles published in lead- 
mood in Japan. Its meaning, however, is nuanced. Jishuku may also be described as broader consideration for others (Schilling, 2OI 5). While it can be attributed to a period of collective mourning, equally it may represent a personalised response to grief (McVeigh, 20I4: I I 5). Such interpretations were not reflected in the way jishuku was presented through the international media coverage, instead it underwrote a cultural narrative by demonstrating the strength of collectivist values within Japanese society (Matthews, 2019)

\section{Conclusions}

This chapter has attempted to elucidate the processes that contribute to shared patterns of meaning and understanding that circulate in international media coverage of disaster. Despite the growth of digital media, a greater diversity of voices in the international public sphere and new forms of mediation, international news organisations remain significant, not only in determining attention and selection, but in establishing the dominant narratives used to explain and interpret issues and events. By elaborating on the features of international media coverage of the 20I I Japan disaster, the discussion above has sought to examine how international news organisations, as important interlocutors within the network multinational flows of information, and the practices inherent to journalism, may contribute to the emergence of shared narratives across journalism contexts. While the hierarchies that exist in the global media system may explain the rendering of an economic narrative in this example, other narratives are a product of the journalistic values and practices that are increasingly shared across journalism cultures. Culture, therefore, became a framework through which to explain and understand 'Japan's' response to the disaster, providing a narrative that would enable distant events to resonate with audiences (Gurevitch, Levy and Roeh, I99I).

ing newspapers including The New York Times (28 March 20II) and le Figaro (3I March 20II). 


\section{References}

Aalberg, T., Strömbäck, J. and de Vreese, C. H. (2012). "The Framing of Politics as Strategy and Game: A Review of Concepts, Operationalizations and Key Findings," Journalism, I3(2), pp. I62-I 78 .

Allan, S. (2013). Citizen Witnessing: Revisioning Journalism in Times of Crisis. Cambridge: Malden, Mass.: Polity Press.

Appadurai, A. (1996). Modernity at Large: Cultural Dimensions of Globalization. Minneapolis: University of Minnesota Press.

Benthall, J. (I993). Disasters, Relief and the Media: London: I.B. Tauris.

Berglez, P. (2013). Global Journalism: Theory and Practice. New York: Peter Lang.

Bird, S. E. and Dardenne, R. W. (2009). "Rethinking News and Myth as Storytelling," in Wahl-Jorgensen, K. and Hanitzsch, T. (eds.) The Handbook of Journalism Studies. London: Routledge, pp. 205-2I 5 .

Boyd-Barrett, O. (2008). "News Agency Majors: Ownership, Control and Influence Reevaluated," Journal of Global Mass Communication, I(2), pp. 57-7I.

Castells, M. (2000). The Rise of the Network Society - Volume I: The Information Age: Economy, Society and Culture, 2nd ed. Blackwell: Oxford.

Clausen, L. (2003). Global News Production. Copenhagen: Copenhagen Business School.

Cottle, S. (2006). "Mediatized Rituals: Beyond Manufacturing Consent," Media, Culture \& Society, 28(3), pp. 4I I-432.

- (20I4). "Rethinking Media and Disasters in a Global Age: What's Changed and Why It Matters," Media, War \& Conflict, 7(I), pp. 3-22.

Cottle, S. and Rai, M. (2006). "Between Display and Deliberation: Analyzing TV News as Communicative Architecture," Media, Culture \& Society, 28(2), pp. I63-189. 
Cooper, G. (20I I). "From Their own Correspondent? News Media and the Changes in Disaster Coverage: Lessons to be Learnt," Reuters Institute for the Study of Journalism.

Daliot-Bul M. (2008). "Eroticism, Grotesqueness and Non-Sense: Twenty-first Century Cultural Imagery of Japan in the Israeli Media and Popular Culture," Journal of Intercultural Studies, 28(2): I73-I9I.

de Vreese, C. H. (2005). "News Framing: Theory and Typology," Information Design Journal \& Document Design, I3(I), pp. 5 I-62.

Elliot, C. W. (2000). "Flows of News from the Middle Kingdom: An Analysis of International News Releases from Xinhua," in Malek, A. and Kavoori, A. P. (eds.) The Global Dynamics of News: Studies in International News Coverage and News Agenda. Stamford, Conn.: Ablex, pp. 343-388.

Elliot, C. (2016). "Inside the Guardian: How the Live Blog has Changed the Face of News Reporting," The Guardian, 4 February (Online). Available at: https://www.theguardian.com/member ship/20 I 6/feb/o4/inside-the-guardian-how-live-blog-changed --ews-reporting (Accessed 24 February 2018).

Gamson, W. A. and Modigliani, A. (1989). "Media Discourse and Public Opinion on Nuclear Power: A Constructionist Approach," American Journal of Sociology, 95(I), pp. I-37.

Gans, H. J. (1980). Deciding What's News: A Study of CBS Evening News, NBC Nightly News, Newsweek, and Time. New York: Pantheon Books.

Guo, L., Holton, A. and Jeong, S. H. (2012). "Transnational Comparative Framing: A Model for an Emerging Framing Approach," International Journal of Communication, Vol. 6, pp. I9I 8-I94I.

Gurevitch, M., Levy, M. and Roeh, I. (I99I). “The global newsroom: Convergences and Diversities in the Globalisation of Television News," in Dahlgren, P. and Sparks, C. (eds.) Communication and Citizenship: Journalism and the Public Sphere in the New Media Age. London: Routledge, pp. I95-2I 5 . 
Heinrich, A. (20II). Network Journalism: Journalistic Practice in Interactive Spheres, Routledge, New York.

Himelboim, I., Chang, T.K. and McCreery, S. (20I0). "International Network of Foreign News Coverage: Old Global Hierarchies in a New Online World," Journalism \& Mass Communication Quarterly, 87(2), pp. 297-3I4.

Iannarino, N. T., Veil, S. R. and Cotton, A. J. (201 5 ). "Bringing Home the Crisis: How US Evening News Framed the 20 I I Japan Nuclear Crisis," Journal of Contingencies and Crisis Management, 23(3), pp. I69-I 8 I.

Jenkins, H. and Deuze, M. (2008). "Editorial: Convergence Culture," Convergence, $\mathrm{I} 4(\mathrm{I}), \mathrm{pp} .5^{-\mathrm{I} 2}$.

Johnson-Cartee, K. S. (2005). News Narratives and News Framing: Constructing Political Reality. Oxford: Rowman \& Littlefield.

Joye, S. (2009). "The Hierarchy of Global Suffering," The Journal of International Communication, I5(2), pp. 45-6I.

Kingston, J. (2013). Contemporary Japan: History Politics and Social Change Since the I980s. Chichester, West Sussex: John Wiley \& Sons.

Kitch, C. (2003). "Mourning in America': Ritual, Redemption, and Recovery in News Narrative after September I ," Journalism Studies, 4(2), pp. 213-224.

Matthews, J. (2019). "Cultural Otherness and Disaster News: The Influence of Western Discourses on Japan in US and UK News Coverage of the 20I I Great East Japan Disaster," International Communication Gazette, 8I(4), pp. 372-392.

McNair, B. (2006). Cultural Chaos: Journalism, News and Power in a Globalised World. Routledge: London.

McVeigh, BJ. (20I4). The Nature of the Japanese State. London: Routledge.

Murrell, C. (20I7). “The Global Television News Agencies and Their Handling of User Generated Content Video from Syria," Media, War \& Conflict, (Online). Available at: doi:I7506352I7704224 (Accessed: I November 20I7). 
Neuman, W. R., Just, M. R. and Crigler, A. N. (I992). Common Knowledge: News and the Construction of Political Meaning. London: University of Chicago Press.

Pan, Z. and Kosicki, G. M. (I993). "Framing Analysis: An Approach to News Discourse," Political Communication, Io(I), pp. 55-75.

Pantti, M., Wahl-Jorgensen, K., and Cottle, S. (2012). Disasters and the Media. New York: Peter Lang.

Paterson, C. (1998). Global Battlefields, in Boyd-Barrett, O. and Rantanen, T. (eds.) The Globalization of News. London: Sage Publications, pp. 79-103.

Rai, M. and Cottle, S. (2007). "Global Mediations: On the Changing Ecology of Satellite Television News," Global Media and Communication, $3(\mathrm{I})$, pp. 5 I-78.

Reese, S. D. (2008). "Theorizing a Globalized Journalism," in Löffelholz, M. and Weaver, D. H. (eds.) Global Journalism Research: Theories, Methods, Findings, Future. Hoboken, NJ: John Wiley \& Sons, pp. 240-252.

Rodríguez, H., Trainor, J. and Quarantelli, E. L. (2006). "Rising to the Challenges of a Catastrophe: The Emergent and Prosocial Behavior following Hurricane Katrina," The ANNALS of the American Academy of Political and Social Science, 604(I), pp. 82-IOI.

Schilling, M. (2015). "Is Japanese Cinema Sinking Into a SelfCensorship Swamp?" The Japan Times, I I February (Online). Available at: https://www.japantimes.co.jp/culture/20 I 5/O2/I I/films /japanese-cinema-sinking-self-censorship-swamp (Accessed I February 201 8).

Schudson, M. (1978). Discovering the News: A Social History of American Newspapers. New York: Basic Books.

$\mathrm{Si}$, Si. (20I4). "Expansion of International Broadcasting: The Growing Global Reach of China Central Television," Working paper: Reuters Institute for the Study of Journalism.

Stock, P. V. (2007). "Katrina and Anarchy: A Content Analysis of a New Disaster Myth," Sociological Spectrum, 27(6), pp. 705-726. 
Sweeney, M. (20I4). "The Guardian Overtakes New York Times in comScore Traffic Figures," the Guardian, 2I October (Online). Available at: https://www.theguardian.com/media/20 I 4/oct/2 I/the -guardian-overtakes-new-york-times-in-comscore-traffic-figures (Accessed I November 20I7).

Tang, W. and Iyengar, S. (2OI2). "Introduction: The Emerging Media System in China: Implications for Regime Change," in Tang, W. and Iyengar, S. Political Communication in China. Convergence or Divergence Between the Media and Political System? London: Routledge, pp. I-6.

Thurman, N. and Rodgers, J. (20I4). "Citizen Journalism in Real Time: Live Blogging and Crisis Events," in E. Thorsen and S. Allan (eds.) Citizen Journalism: Global Perspectives, Volume 2. New York: Peter Lang, pp. 8I-95.

Thussu, D. K. (2006). Media on the Move: Global Flow and ContraFlow. London: Routledge.

Tierney, K., Bevc, C. and Kuligowski, E. (2006). "Metaphors Matter: Disaster Myths, Media Frames, and Their Consequences in Hurricane Katrina," The ANNALS of the American Academy of Political and Social Science, 604(I), pp. 57-8I.

Tong, J. (20I4). "Environmental Risks in Newspaper Coverage: A Framing Analysis of Investigative Reports on Environmental Problems in Io Chinese Newspapers," Environmental Communication, 8(3), pp. 345-367.

Tunstall, J. (2008). The Media Were American: U.S. Mass Media in Decline. New York: Oxford University Press.

Van Gorp, B. (2007). “The Constructionist Approach to Framing: Bringing Culture Back In," Journal of Communication, 57(I), pp. $60-78$.

Volkmer, I. (2014). Global Public Sphere: Public Communication in the Age of Reflective Interdependence, Cambridge: Polity Press.

Volkmer, I. and Heinrich, A. (2008). "CNN and Beyond: Journalism in a Globalized Network Sphere" in J. Chapman and M. Kinsey (eds.) Broadcast Journalism: A Critical Introduction. Routledge: London, pp. 49-57. 
Wardle, C., and Williams, A. (2010). "Beyond User-Generated Content: A Production Study Examining the Ways in Which UGC is Used at the BBC," Media, Culture \& Society, 32(5), 78 I-799.

Watanabe, K. (2013). "The Western Perspective in Yahoo! News and Google News," International Communication Gazette, 75(2), pp. I4I-I 56.

Watts, J. (20I I) "Japan Earthquake: Stories from Across the Disaster Zone," The Guardian, I 8 March (Online). Available at: https:// www.theguardian.com/world/20 I I/mar/ I 8/japan-earthquake -stories-disaster-zone (Accessed: 24 October 2017).

Weaver, D. (1998). "Journalists Around the World: Commonalities and Differences," in Weaver, D. (ed.) The Global Journalist: News People Around the World. Cresskill, NJ: Hampton Press, pp. 45 5-480.

Wu, H. D. (2003). “Homogeneity Around the World?” International Communication Gazette, 65(I), pp. 9-24.

Zelizer, B. and Allan, S. (2010). Keywords in News and Journalism Studies. Maidenhead: McGraw Hill/Open University Press. 